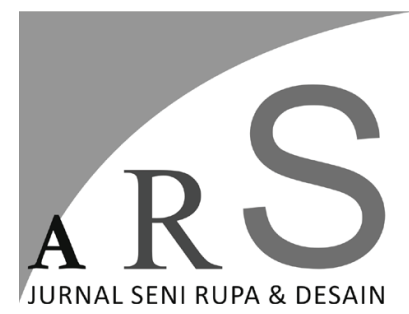

Volume 21 Nomor 3 - Desember 2018

\section{PERANCANGAN IDENTITAS VISUAL KOTA SALATIGA SEBAGAI KOTA MULTIKULTUR DAN TOLERAN}

\author{
Danang Adi Wiratama \\ JL. Kebon Kembang No.1, Tamansari, Bandung \\ Institut Teknologi Bandung \\ E-mail: danangadiwiratama@gmail.com
}

\begin{abstract}
ABSTRAK
Tujuan dari penalitian ini adalah menghasilkan sistem identitas visual Kota Salatiga yang merepresentasikan spirit keberagaman dan toleransi melalui logo dan aplikasinya pada berbagai media. Penelitian menggunakan pendekatan kualitatif melalui studi literatur, observasi, dan wawancara sehingga menjadi acuan terhadap penyusunan konsep branding, perancangan identitas visual, dan aplikasinya ke berbagai media. Dari analisis dihasilkan "big idea" branding Kota Salatiga sebagai "Salatiga: Miniatur Indonesia”yang berarti bahwa multikulturalisme dan toleransi di Kota Salatiga merupakan miniatur (cerminan nyata) dari spirit ke-Indonesia-an yang begitu beragam namun tetap satu jua. Kemudian strategi komunikasi "Tiga M" (Mari Datang, Mari Kenal, Mari Gabung) juga menjadi strategi komunikasi yang dirasa cocok mewadahi berbagai potensi Kota Salatiga. Gagasan branding Salatiga ini diterjemahkan ke dalam logo berkonsep "Tiga Wajah" yang menggambarkan multikulturalisme, toleransi, keramah-tamahan, keharmonisan, dan legenda Salatiga. Sistem logo dibuat fleksibel dan mempunyai banyak peluang aplikasi agar merepresentasikan spirit keanekaragaman. Selanjutnya, identitas "Salatiga: Miniatur Indonesia" diterapkan dalam berbagai aplikasi seperti stationary, environmental graphics, booklet, website, video, dan suvenir.
\end{abstract}

Kata Kunci: citybranding, identitas visual, Salatiga, multikulturalisme, toleransi

\begin{abstract}
The aim of the researchis to create a system of Salatiga's visual identity representing it's diversity and tolerance spirit through logo and applications over a broad range of media. The research uses qualitative method through document study, observation, and interview so that became reference of creating the branding concept, designing the visual identity, and the applications across media. The analysis generates the big idea of Salatiga Citybranding as "Salatiga: Miniatur Indonesia" meant the multiculturalism and tolerance in Salatiga City is a miniature (true reflection) of Indonesia's spirit of unity in diversity. The communication strategy of "Three M" (Mari Datang, Mari Kenal, Mari Gabung) is found as an effective communication strategy which accommodated lots of Salatiga City's potencies. The notion of Salatiga Citybranding was translated into "Three Faces"concept logo representing multiculturalism, tolerance, hospitality, harmony, and the legend of Salatiga. The logo system is flexible and allows many chance of creative application so that could represent the spirit of multiculturalism. Moreover, the identity of "Salatiga: Miniatur Indonesia" is applied on several media such as stationary, booklet, environmental graphics, website, video, and gimmicks
\end{abstract}

Keywords: citybranding, visual identity, Salatiga, multiculturalism, tolerance 


\section{Pendahuluan}

Pemerintah Kota Salatiga menyadari adanya ancaman Salatiga menjadi 'kota mati' pasca dibukanya jalur Tol Trans Jawa yang melewati Kota Salatiga pada tahun 2017. Dikhawatirkan orang akan melalui Kota Salatiga bukan lagi untuk disinggahi (Salatiga dikenal sebagai kota transit pariwisata), melainkan menjadi sekadar hanya untuk dilewati. Gubernur Jawa Tengah, Ganjar Pranowo menyebutkan bahwa Kota Salatiga tidak perlu khawatir akan ancaman menjadi 'kota mati' jika mempunyai gagasan menjadi kota yang menarik untuk disinggahi. (Munir, 2017)

Kota Salatiga sebagai salah satu kota terkecil di Indonesia, keberadaannya seolah kurang mendapat perhatian dibandingkan dengan kotakota besar sekitarnya. Salatiga diduga belum mempunyai citra yang kuat di benak masyarakat luas mengenai identitas sejatinya. Sekalipun demikian, Kota Salatiga sebenarnya menyimpan begitu banyak potensi yang menarik. Misalnya, posisi geografis Salatiga yang menjadikan kota ini sebagai kota transit pariwisata, beragam kuliner khas, Prasasti Plumpungan yang menjadi bukti tuanya peradaban kota ini, serta suasana nostalgia dari beragam bangunan berarsitektur kolonial. (Supangkat, 2012: 67,88)

Selain keunggulan-keunggulan fisik di atas, hal menarik lainnya adalah bahwa masyarakat Salatiga dikenal sebagai masyarakat yang multikultur. Ada begitu banyak pendatang lain dari seluruh Indonesia yang memilih untuk tinggal di kota sekecil Salatiga. Kebanyakan berada di Salatiga karena alasan pendidikan namun setelah itu, cukup banyak juga yang memutuskan untuk tinggal menetap di kota ini. Itulah sebabnya Salatiga juga dikenali sebagai "Indonesia Mini". (Supangkat, 2012: xiv) (Widiarto et al., 2006:99) Tingginya keberagaman masyarakat dan budaya di Salatiga sebenarnya mengakibatkan tingginya juga potensi perpecahan. Namun faktanya kehidupan antar masyarakat di Salatiga sangatlah harmonis dan kerap kali diwarnai dengan banyak hal yang mengangkat tinggi semangat toleransi. Mulai dari adanya parade antar budaya tiap tahun, hingga tradisi natal bersama di depan masjid alun-alun kota.
Lebih dari sekadar event-event seremonial, tingginya toleransi antar budaya dan kepercayaan di Salatiga sebenarnya sudah mengakar dalam kehidupan masyarakatnya. Munculnya berbagai gerakan pro-toleransi melalui komunitaskomunitas maupun LSM di Salatiga menjadi bukti nyata betapa toleransi begitu dirindukan masyarakat untuk senantiasa ada dan tegak berdiri di bumi Salatiga. Beberapa gerakan ini mengilhami kemunculan gerakan serupa di beberapa kota-kota lainnya dan bahkan tahun 2004, para uztad dan pendeta Belanda secara khusus menyambangi Salatiga demi belajar mengenai toleransinya. Dari segi pemerintahan, pemerintah Kota Salatiga pada tahun 2015 tengah menggodog rancangan peraturan daerah (Raperda) Wawasan Kebangsaan yang mengatur tentang keberlangsungan tegaknya nilai toleransi dan nasionalisme di tengah masyarakat Salatiga yang begitu heterogen. (http://deklarasi-sancang.org/salatiga-denganwarga-berbhineka) Puncaknya terjadi pada tahun 2015 saat Setara Institute (organisasi non-profit yang memperjuangkan demokrasi, kebebasan berpolitik, dan HAM) menyatakan bahwa Salatiga menempati posisi kedua paling tinggi toleransinya dari 94 kota di Indonesia. (Wisnu, 2015)

Identitas sekaligus keunggulan Kota Salatiga berupa keberagaman dan toleransi antar masyarakatnya belum pernah secara sistematis diperkenalkan sebagai branding Salatiga sehingga banyak orang tidak mengetahuinya. Kebanyakan promosi kota dilakukan hanya oleh segelintir kalangan dengan berfokus pada sisi pariwisatanya tanpa mengekspose identitas Salatiga berupa keberagaman dan toleransinya. Padahal bila ditilik lebih lanjut, keberagaman dan toleransi ini bisa menjadi poin unik dan pembeda Salatiga dari kota-kota sekitarnya yang kebanyakan berpusat pada sisi pariwisata. Dengan mengangkat isu keberagaman dan toleransi, Salatiga diharapkan bisa menularkan semangat Bhinneka Tunggal Ika di tengah kondisi bangsa yang cukup sering diwarnai dengan konflik antar golongan. Identitas Salatiga seperti inilah yang harus diperkenalkan kepada masyarakat luas melalui media-media visual agar mudah dipahami. 
Atas dasar itulah, peneliti tertarik untuk merancang identitas visual Kota Salatiga. Dalam perancangan ini, peneliti akan melakukan riset mengenai multikulturalisme dan toleransi di Kota Salatiga kemudian merumuskannya dalam strategi komunikasi secara visual. Identitas visual yang akan dirancang penulis berupa logo dan berbagai aplikasinya pada brosur, website, poster, video, dan suvenir yang merepresentasikan identitas keberagaman dan toleransi di Salatiga. Diharapkan identitas visual dan penerapannya di media-media yang terencana seperti ini akan efektif memberi gambaran yang jelas, menarik, dan konsisten bagi wisatawan maupun masyarakat umum mengenai "siapakah Salatiga".

Berdasarkan latar belakang tersebut, dapat dirumuskan masalah pokok perancangan ini adalah (1) kebutuhan terhadap konsep branding Kota Salatiga sebagai kota multikultur dan toleran, (2) kebutuhan terhadap identitas visual yang merepresentasikan identitas Kota Salatiga itu, dan (3) kebutuhan akan media-media yang efektif bagi penerapan identitas visual Kota Salatiga. Dari sini bisa dipetakan tujuan perancangan ini adalah (1) merumuskan ide branding termasuk strategi komunikasi branding Salatiga, (2) merancang identitas visual berupa logo dan sistem aplikasinya, dan (3) menerapkan strategi komunikasi dan identitas visual ini ke berbagai media yang efektif.

Berikut ini peninjauan terhadap teori-teori dasar mengenai branding, citybranding, dan brand identity. Moilanen dan Rainisto (2009:6) menuturkan bahwa brand adalah impresi yang diterima di benak klien dari suatu produk atau servis. Suatu brand bukanlah hanya merupakan sebuah simbol yang membedakan produk satu dengan lainnya, tapi juga melingkupi semua atribut yang datang kepada benak konsumen ketika mereka memikirkan brand tersebut. Atribut ini mencakup segala fitur tangible, intangible, psikologis, dan sosiologis yang terkait dengan brand tersebut. (Moilanen et al., 2009:6) Gardner dan Levy dalam Kavaratzis dkk. (2015:16) bahkan berpendapat bahwa citra yang diwakili oleh simbol abstak ini (baca: brand) barang kali lebih penting daripada kualitas teknis dari produk yang diwakilinya. Pada akhirnya, pengembangan suatu brand dirasa harus ditekankan pada asosiasi emosional daripada sekadar asosiasi fungsional saja. Dengan demikian, pengertian dari branding sebenarnya tidak hanya berbicara mengenai usaha pembuatan simbol visual semata, melainkan lebih luas, yaitu suatu usaha untuk menciptakan impresi yang benar dalam benak konsumen mengenai produk yang ditawarkan melalui media apa saja.

Keilmuan branding pada awalnya merupakan keilmuan yang diterapkan pada produk (barang dan jasa), namun dalam perkembangannya ternyata konsep brand meluas ke berbagai objek seperti orang dan tempat. Citybranding merupakan branding yang dilakukan terhadap suatu kota. Citybranding adalah upaya untuk memasarkan suatu kota agar dirinya dikenali sebagai suatu hal yang beridentitas, unik dan berbeda. Dengan menerapkan branding, sebuah kota mampu membangun identitas yang jelas, asosiasi yang kuat, dan menyematkan atribut positif agar mampu menempatkan diri dan memenangkan persaingan dengan kota lainnya. (Yananda, M.Rahmat, 2014:55)

Pakar citybranding mengungkapkan bahwa membranding sebuah tempat memiliki kompleksitas yang begitu tinggi dibandingkan dengan membranding produk atau servis. (Dinnie, 2011:16) Hal ini dikarenakan pemangku kepentingan yang relatif banyak, kompleksitas yang tinggi, berkaitan dengan tanggungjawab sosial, berkaitan dengan identitas yang bermacammacam, dan membutuhkan pembangunan dalam jangka waktu yang lama. (Yananda, M.Rahmat, 2014:62) Dengan segala pengertian tersebut hakikat branding kota bisa dimaknai sebagai usaha sistematis dan konsisten suatu kota untuk membangun citra kota melalui segala aspek yang dimiliki oleh kota tersebut sebagai identitasnya.

$$
\text { Moilanen dan Rainisto (2009:7) }
$$
menjelaskan tiga konsep utama terkait dengan brand, yaitu: identitas, citra, dan komunikasi. Identitas sebuah brand merupakan apapun yang diharapkan perusahaan untuk diasosiasikan dengan brand yang dimilikinya. Identitas sebuah brand ditentukan oleh pembuat brand itu sendiri sementara citra brand merupakan kesan apa yang berada di benak konsumen. Komunikasi 
diperlukan untuk menyampaikan pesan mengenai identitas brand sehingga akan mempengaruhi citra brand (bagaimana itu dipersepsikan oleh para pengguna).

Karena citra brand merupakan hasil jangka panjang dari proses branding dan tercipta di benak pelanggan, bisa disadari bahwa sebenarnya upaya branding berkutat pada dua hal yaitu identitas dan komunikasi di mana identitas menjadi pangkal proses pembangunan citra tersebut. Bisa disadari bahwa langkah pertama yang harus dilakukan untuk membranding suatu kota adalah untuk memahami identitas kota itu.

Sama seperti seseorang yang bisa memiliki identitas berbeda pada waktu yang sama, identitas brand suatu kota juga sebanarnya merupakan konsep yang bersifat banyak muka. Yananda dan Salamah (2014:65-66) menyebutkan bahwa identitas kota tersimpan dalam beberapa hal yaitu: (1) artefak fisik yang menjadi penanda kota, (2) dokumen tentang masa lalu, masa kini, dan kota di masa yang akan datang, dan (3) memori kolektif kelompok yang menjadi pemangku kepentingannya. Citybranding menjadi cara cerdas untuk menemukan esensi suatu kota di dalam segala kompleksitas identitasnya. Citybranding mencari benang merah suatu kota, mengandalkan apa yang benar-benar sudah dimilikinya, dan mengejar ketertinggalannya dengan modal yang sebenarnya selalu ada dan menjadi kekuatan kota (Yananda, M.Rahmat, 2014:85)

Identitas brand memiliki arti luas yaitu sekumpulan asosiasi mental dan fungsional yang dimiliki oleh suatu brand (http:// managementstudyguide.com/brand-identity. htm), atau dalam bahasa yang lebih sederhana bisa diartikan sebagai segala sesuatu yang dimiliki suatu brand yang mengasosiasikan brand tersebut. Identitas brand bisa bersifat tangible (terlihat) dan intangible (tak terlihat). Identitas tangible berarti merujuk pada elemen-elemen fisik milik perusahaan yang dapat dikenali secara indrawi. (Wheeler, 2013:4) Identitas tangiblebrand kota dapat berupa artefak-artefak fisik, kondisi geografis, dan seni budayanya, hingga berupa halhal yang sengaja dibentuk seperti logo branding kotanya. Sementara itu, identitas brandintangible misalnya seperti kerukunan, toleransi, dan keramah-tamahan, ataupun yang lahir dari proses strategis branding misalnya seperti personalitas brand kota, konsep branding kota, positioning, dan strategi branding kota itu sendiri. Inti kesamaan dari semua hal yang menjadi identitas brand suatu kota adalah bahwa hal-hal itu dapat mengasosiasikan atau "mengingatkan orang" akan kota tersebut.

Secara spesifik, Alina Wheeler (2013:4) menjelaskan bahwa brand identity merupakan sesuatu yang tangible (bisa dirasakan secara indrawi). Kita bisa melihatnya, menyentuhnya, memegangnya, mendengarnya, dan lain sebaganya. Brand identity merupakan bahan bakar dari sebuah brand agar diakui, menguatkan adanya perbedaan dengan brand lain, dan membuat ideide besar yang kompleks menjadi dapat dipahami. Brand identity menyatukan berbagai elemenelemen sehingga bisa menjadi suatu sistem. Brand identity merupakan media bagi sebuah brand mencapai pelanggan. Artinya bahwa nilai-nilai yang terkandung dari sebuah brand bisa sampai dan dipahami oleh para pelanggan melalui brand identity ini. Contoh brand identity ini misalnya berupa logo, tagline, maskot, suvenir, kemasan, website, dan lain sebagainya. Wheeler (2013:102) menerangkan bahwa setidaknya ada lima tahap dalam membuat brand identity:

\section{Conducting Research}

Langkah pertama yang harus dilakukan adalah untuk memahami entitas yang akan dibuat identitas brandnya. Pemahaman yang dimaksud adalah pemahaman mengenai visi, misi, target pemasaran, budaya perusahaan, keunggulan, kelemahan, strategi pemasaran, dan tantangan masa depan. Selain itu persepsi para pemangku kepentingan, aspek sejarah, dan pemetaan kompetisi dengan brand lain juga perlu dilakukan dalam tahap ini. Prakteknya, bisa dilakukan dengan cara kualitatif (misalnya studi literatur, etnografi, FGD, wawancara) dan kuantitatif (misalnya survey online, eye tracking, segmentasi).

\section{Clarifying Strategy}

Pada tahap ini dilakukan analisis dan sintesis terhadap temuan riset yang telah dilakukan. Dari 
sana, hasilnya akan menjadi bahan baku bagi ditetapkannya core valuebrand, positioning, pesan utama brand, voice and tone, dan strategi branding secara keseluruhan. Kumpulan keputusan ini oleh Wheeler dinamakan sebagai "big idea".

\section{Designing Identity}

Tahap pendesainan identitas merupakan tahap saat big idea branding yang abstrak diterjemahkan ke dalam bentuk-bentuk konkrit yang dapat dengan mudah dicerna. Disinilah tahap di mana kepekaan seorang desainer sangat dibutuhkan untuk berkerja. Desainer perlu memiliki keahlian tinggi dalam menerjemahkan ide-ide kompleks menjadi esensi visual. Dalam bagian ini diperlukan perhatian ekstra dalam merancang logo, look and feel, warna, tipografi, aplikasi, bahkan suara dan animasi.

\section{Creating Touchpoints}

Setelah desain disetujui, disinilah tahap menentukan penerapan desain dalam segala aplikasi. Aplikasi-aplikasi desain yang dimaksud adalah seperti website, pictogram, surat-surat resmi, kartu nama, sign system, kemasan, iklan, grafis transportasi, suvenir, seragam, dan lain sebagainya. Tantangan yang dihadapi dalam tahap ini adalah untuk menjaga keseimbangan antara fleksibilitas ekspresi dengan konsistensi komunikasi yang ada di tiap media yang digunakan.

\section{Managing Assets}

Managing Assets adalah tahapan di mana para stakeholder dalam sebuah brand mengatur manajemen sedemikian rupa untuk menjamin keberlangsungan dan konsistensi penggunaan brand identity untuk jangka waktu yang panjang. Dalam tahapan ini diperlukan cara-cara jitu untuk memasyarakatkan "brand baru" ini yang pertama kepada pihak internal perusahaan kemudian baru setelah itu pihak luar perusahaan.

\section{Pembahasan}

\section{Gambaran Singkat Kota Salatiga}

Salatiga merupakan kota kecil di Jawa Tengah (49 km di selatan Kota Semarang atau $52 \mathrm{~km}$ di utara Kota Surakarta) yang terletak di jalan negara yang menghubungkan Semarang dan Surakarta. Salatiga terletak di kaki Gunung Merbabu tepatnya pada ketinggian 450-800 mdpl sehingga memiliki hawa yang relatif sejuk. Salatiga hanya terdiri atas empat kecamatan, yakni Argomulyo, Tingkir, Sidomukti, dan Sidorejo dan menempati luas wilayah kurang lebih $56.78 \mathrm{~km}^{2}$. (Salatiga, 2015)

Kota Salatiga memiliki keistimewaan jika ditinjau dari segi sejarahnya. Keberadaan Salatiga dipastikan telah ada sejak tahun 24 Juli tahun 750 Masehi berdasarkan pada Prasasti Plumpungan yang berada di Desa Plumpungan, Salatiga. (Supangkat, 2012:90) Keberadaan prasasti ini seolah menjadi bukti paten bahwa peradaban di Salatiga telah berjalan begitu lama (1260 tahun lebih) dan sesuatu yang penting dan istimewa pernah terjadi di wilayah ini.

Supangkat $(2012: 88,91)$ menjelaskan bahwa lewat prasasti tersebut bisa diketahui dulunya Salatiga merupakan wilayah bernama Desa Hampra yang merupakan bagian dari Kerajaan Mataram Hindu. Desa Hampra bukanlah desa biasa karena desa ini ditetapkan sebagai daerah perdikan (otonomi). Lewat Prasasti Plumpungan disebutkan bahwa Desa Hampra dibebaskan dari segala kewajiban pajak yang harus dipenuhi kepada pusat Kerajaan Mataram Hindu yang sedang bertahta.

Kota Salatiga dikenal sebagai kota dengan nuansa nostalgia yang kental yang tercermin dalam arsitektur bangunan-bangunannya. Kondisi alamnya yang sejuk, indah, dan bersahabat membuat Salatiga menjadi kota pilihan bagi orang kulit putih pada zaman Belanda untuk beristirahat dan tempat tinggalnya. Bahkan oleh pemerintah Hindia Belanda, Kota Salatiga pernah mendapat predikat sebagai "de Schoonste Stad van Midden Java" yang berarti kota terindah di Jawa Tengah(Supangkat, 2012:1). Rahardjo (2015:6,8) berpendapat bahwa banyaknya pendatang orang kulit putih yang tinggal di Salatiga dalam kurun waktu yang relatiflama berdampak pada terjadinya akulturasi kebudayaan. Selain nampak sekali dari segi arsitektur bangunan-bangunannya, dari segi sosial pun keberadaan masyarakat asing membuat masyarakat Salatiga lama-lama menjadi terbiasa dengan adanya perbedaan. 
Saat ini, perbedaan juga sangat terasa dari segi latar belakang budaya antar masyarakatnya. Sama seperti perbedaan yang dialami antara pendatang dan pribumi, masyarakat Salatiga zaman sekarang diperhadapkan dengan pendatang dari hampir seluruh provinsi di Indonesia. Keberadaan mereka di Kota Salatiga kebanyakan adalah karena alasan pendidikan walaupun tak sedikit juga yang pada akhirnya berkeluarga (Widiarto et al., 2006:419) dan menetap di kota ini.

Tingginya keberagaman masyarakat dan budaya di Salatiga pada sisi-sisi tertentu sebenarnya juga mengakibatkan tingginya potensi perpecahan. Namun faktanya, kehidupan antar masyarakat di Salatiga sangatlah harmonis dan kerap kali diwarnai dengan berbagai macam hal yang mengangkat tinggi semangat toleransi. Spirit kebhinnekaan seperti inilah yang menjadikan banyak orang menyebut Salatiga sebagai kota multikultur atau "Indonesia Mini".

\section{Multikulturalisme dan Toleransi Kota Salatiga}

Sebutan Salatiga sebagai kota multikultur dan Indonesia Mini sebenarnya berangkat dari sebutan yang disematkan pada Universitas Kristen Satya Wacana (UKSW), sebuah universitas swasta di Salatiga. UKSW pada awalnya bernama Perguruan Tinggi Pendidikan Guru Kristen Indonesia (PTPG-KI). Setelah didirikan (1956), PTPG-KI ditetapkan sebagai perguruan tinggi terbuka, artinya menerima mahasiswa yang memenuhi syarat akademik dari semua suku, daerah, agama dan kebangsaan. Sebutan "Indonesia Mini" yang muncul kemudian sudah tercermin dari komposisi mahasiswa angkatan pertama yang sudah menunjukkan keberagaman suku dan budaya dari berbagai daerah di Indonesia. (Widiarto et al., 2006:99)

Kehadiran perguruan tinggi di kota sekecil Salatiga sudah pasti merupakan sesuatu yang begitu mempengaruhi situasi kota. Pengaruh yang dirasakan begitu beragam mulai dari segi pendidikan itu sendiri, ekonomi, hingga sosial budaya. Kehadiran berbagai mahasiswa dari hampir seluruh provinsi di Indonesia tentu saja membawa nuansa yang berbeda pada interaksinya dengan masyarakat pribumi (suku Jawa) di Salatiga (terutama) yang hidup berdampingan dengan para mahasiswa ini.

Contoh pola interaksi yang menarik antara penduduk lokal dan pendatang di ranah kemahasiswaan misalnya tercermin dengan adanya tradisi parade budaya nusantara pada saat Penerimaan Mahasiswa Baru (PMB). Puncak pergaulan antar suku ini mungkin tercermin pada adanya fenomena perkawinan antar suku. Banyak mahasiswa dari berbagai provinsi setelah lulus pada akhirnya memutuskan untuk membangun keluarga dan menetap di Salatiga. Dialog antar suku terwujud dalam proses sosialisasi yang berbau kekeluargaan dan semuannya menampakkan hakekat masyarakat Indonesia yang sebenarnya: berbeda-beda tapi satu. (Widiarto et al., 2006:419)

Selain itu, kehidupan multikultural dan toleransi di Salatiga juga bisa dilihat dari keharmonisan kehidupan antar umat beragamanya. Ada hal-hal menarik khas Kota Salatiga yang terjadi pada saat hari raya keagamaan. Mulai dari adanya dialog antar agama, hingga tradisi natal bersama di depan masjid alun-alun kota dengan penjagaan keamanan dari umat yang berbeda.

Lebih dari sekadar event seremonial, tingginya toleransi antar budaya dan kepercayaan di Salatiga sebenarnya sudah sangat mengakar dalam kehidupan masyarakatnya. Munculnya berbagai gerakan pro-toleransi melalui komunitas maupun LSM di Salatiga menjadi bukti nyata betapa toleransi begitu dirindukan masyarakat untuk senantiasa tegak berdiri di kota ini. Beberapa gerakan ini mengilhami kemunculan gerakan serupa di beberapa kota-kota lainnya seperti di kota Solo, Jogja, dan Lampung. Bahkan pada tahun 2004, para uztad dan pendeta Belanda secara khusus menyambangi Salatiga demi belajar mengenai toleransinya. Puncaknya mungkin terjadi pada 16 November 2015 saat Setara Institute (organisasi non-profit Indonesia yang bergerak dalam memperjuangkan demokrasi, kebebasan berpolitik, dan HAM) menyatakan bahwa Salatiga menempati posisi kedua paling tinggi toleransinya dari 94 kota di Indonesia. (Wisnu, 2015)

Bila ditarik ke belakang, tingginya nilai toleransi antar masyarakat di Salatiga bukanlah 
hasil dari suatu program terstruktur pemerintah namun lebih mengenai sesuatu yang dipelihara dari masa ke masa. Peneliti sejarah Salatiga, Slamet Raharjo, saat diwawancarai menyebutkan bahwa kehidupan multikultural di Salatiga telah ada sejak zaman Prasasti Plumpungan. Pada masa itu, ada beberapa kepercayaan yang dianut oleh masyarakat seperti agama Hindu, Budha, dan penghormatan pada roh nenek moyang.Prasasti Plumpungan ini secara tersirat menunjukkan bahwa "tanda prestasi" ini diraih di dalam masyarakat yang begitu beragam kepercayaannya. Inilah yang menjadikan Prasasti Plumpungan begitu istimewa, tak hanya karena keberadaannya, namun juga karena kondisi masyarakat setempat ketika prasasti itu ditahbiskan.

Selain Prasasti Plumpungan, "kelahiran" Kota Salatiga juga tidak lepas dari pengaruh penyebaran agama Islam di tanah Jawa. Melalui Walisongo, penyebaran agama Islam memberi dampak yang besar bagi kebudayaan masyarakat Jawa, khususnya Salatiga. Nama salah satu sunan yakni Sunan Kalijaga disebutkan dan menjadi tokoh sentral dalam Legenda Kota Salatiga. Dalam legenda ini, diceritakan bahwa nama "Salatiga" lahir dari kata "salah" dan "tiga" yang menggambarkan kesalahan tiga orang yang ada dalam cerita legenda tersebut. Ketokohan Sunan Kalijaga dalam Legenda Kota Salatiga menunjukkan bahwa setelah era kejayaan Hindu-Budha, nafas Islami juga hadir di Salatiga melanjutkan estafet pembangunan identitas kota.

Tak hanya Hindu, Budha, dan Islam, keberadaan pemerintahan Belanda pada zaman kolonial juga turut memperkaya khazanah multikultural yang dimiliki Kota Salatiga. Tercatat melalui Staatsblad No. 266 tahun 1917 yang dikeluarkan oleh Gubernur Jendral Hindia Belanda, Salatiga ditetapkan sebagai sebuah Gemeente (kota praja). Pemerintah Belanda menyatakan untuk menjadi sebuah Gemeente, di kota tersebut minimal ditinggali oleh $10 \%$ orang kulit putih. Kulit putih dalam kriteria ini bukan semata-mata orang Belanda, melainkan juga orang-orang Eropa non-Belanda dan bangsa lain (termasuk etnis Cina) yang disejajarkan dengan orang Belanda (Supangkat 2012:15). Rahardjo
(2015:6,8) berpendapat bahwa banyaknya pendatang yang tinggal di Salatiga dalam kurun waktu yang relatif lama berdampak pada terjadinya akulturasi kebudayaan. Selain nampak dari segi arsitektur bangunan-bangunannya, dari segi sosial pun keberadaan masyarakat asing membuat penduduk Salatiga menjadi terbiasa dengan adanya perbedaan.

Setelah masuk pada era kemerdekaan, kemunculan Universitas Kristen Satya Wacana (UKSW) pada tahun 1956 semakin menguatkan identitas Kota Salatiga sebagai kota multikultur. Tak hanya sampai di situ, keinginan masyarakat Salatiga akan keharmonisan dalam keragaman juga terpancar dari munculnya gerakan-gerakan dan komunitas pro-toleransi yang ada di kota ini. Pada tataran pemerintahan kota, wacana mengenai kebhinnekaan dan toleransi Salatiga juga menjadi bahasan tersendiri. Salah satu langkah nyata pemerintah Kota Salatiga adalah dengan membentuk Forum Kerukunan Umat Beragama (FKUB) yang berfungsi khusus dalam memelihara nilai-nilai toleransi dalam masyarakat Salatiga.Selain FKUB, identitas Salatiga sebagai kota multikultur dan toleran juga mendapat tindak lanjut serius berupa penyusunan Rancangan Peraturan Daerah (Raperda) Wawasan Kebangsaan oleh DPRD yang mengatur tentang keberlangsungan tegaknya nilai toleransi dan nasionalisme di tengah masyarakat Salatiga yang begitu heterogen.

\section{Persepsi Masyarakat terhadap Kota Salatiga}

Pada 23 November sampai 1 Desember 2015 dilakukan penyebaran kuesioner online untuk mengetahui persepsi masyarakat mengenai Kota Salatiga. "Masyarakat" di sini dibedakan menjadi penduduk Salatiga (minimal berdomisili 10 tahun) dan bukan penduduk Salatiga (tidak berdomisili di Salatiga, berdomisili sementara dan kurang dari 10 tahun). Pertanyaan yang diberikan bersifat terbuka yaitu: "Apa yang ada di benak Anda saat membayangkan Kota Salatiga?".

Kuesioner diisi oleh 212 responden (berusia 17-65 tahun) di mana 148 orang adalah penduduk Salatiga dan 64 bukan penduduk Salatiga. Dari hasil kuesioner tersebut, kata-kata kunci yang terkait dikelompokkan untuk kemudian dihitung 
seberapa sering kata-kata itu disebutkan. Berikut ini adalah tabel urutan 10 persepsi teratas dari penduduk Salatiga dan bukan penduduk Salatiga mengenai Kota Salatiga:

Tabel 1. Persepsi penduduk Salatiga tentang Kota Salatiga

\begin{tabular}{clc}
\hline Urutan & \multicolumn{1}{c}{ Persepsi } & \multicolumn{1}{c}{$\begin{array}{c}\text { Banyak } \\
\text { Penyebutan (kali) }\end{array}$} \\
\hline 1 & $\begin{array}{l}\text { Kuliner enak, } \\
\text { murah, khas }\end{array}$ & 112 \\
\hline 2 & $\begin{array}{l}\text { Nyaman, tentram, } \\
\text { damai, aman, tenang }\end{array}$ & 99 \\
\hline 3 & Sejuk, dingin, adem & 87 \\
\hline 4 & $\begin{array}{l}\text { Tempat-tempat } \\
\text { spesifik }\end{array}$ & 44 \\
\hline 5 & Kota kecil & 31 \\
\hline 6 & $\begin{array}{l}\text { Kenangan, membuat } \\
\text { rindu }\end{array}$ & 26 \\
\hline 7 & Toleransi & 16 \\
\hline 8 & $\begin{array}{l}\text { Indonesia Mini, } \\
\text { multikultur }\end{array}$ & 15 \\
\hline 9 & $\begin{array}{l}\text { Tidak ada } \\
\text { kemacetan }\end{array}$ & 15 \\
\hline 10 & $\begin{array}{l}\text { Ramah } \\
\text { penduduknya }\end{array}$ & 15 \\
\hline
\end{tabular}

(Sumber: dok. Danang, 2015).

Tabel 2. Persepsi penduduk bukan Salatiga tentang Kota Salatiga

\begin{tabular}{clc}
\hline Urutan & \multicolumn{1}{c}{ Persepsi } & $\begin{array}{c}\text { Banyak } \\
\text { Penyebutan (kali) }\end{array}$ \\
\hline 1 & $\begin{array}{l}\text { Kuliner enak, } \\
\text { murah, khas }\end{array}$ & 35 \\
\hline 2 & Sejuk, dingin, adem & 35 \\
\hline 3 & $\begin{array}{l}\text { Tempat-tempat } \\
\text { spesifik }\end{array}$ & 26 \\
\hline 4 & $\begin{array}{l}\text { Nyaman, tentram, } \\
\text { damai, aman, tenang }\end{array}$ & 22 \\
\hline 5 & $\begin{array}{l}\text { Pendidikan } \\
\text { sekolah-sekolah } \\
\text { spesifik, kota } \\
\text { pelajar) }\end{array}$ & 18 \\
\hline 6 & Kota kecil & 12 \\
\hline 7 & $\begin{array}{l}\text { Kenangan, membuat } \\
\text { rindu }\end{array}$ & 9 \\
\hline 8 & Toleransi & 8 \\
\hline 9 & $\begin{array}{l}\text { Indonesia Mini, } \\
\text { multikultur }\end{array}$ & 5 \\
\hline 10 & $\begin{array}{l}\text { Tidak ada } \\
\text { kemacetan }\end{array}$ \\
\hline
\end{tabular}

(Sumber: dok. Danang, 2015).
Berdasarkan data kuesioner yang sudah didapatkan, terlihat jelas bahwa hampir seluruh persepsi terhadap Kota Salatiga baik dari penduduknya maupun bukan, adalah persepsi yang positif. Yananda dan Salamah (2014:40) menyebutkan bahwa citybranding dimanfaatkan sebagai upaya untuk memelihara citra (positif) kota yang dimiliki. Caranya adalah dengan mengoptimalkan identitas yang dimiliki kota demi meningkatkan daya saing yang dimiliki kota tersebut.

Sekalipun tidak pada urutan pertama, masuknyapoin "toleransi" dan "multikulturalisme" dalam daftar tersebut mengindikasikan masyarakat yang sudah menyadari bahwa nilainilai ini merupakan bagian tak terpisahkan dari Kota Salatiga. Tak hanya sampai di situ, hal ini menunjukkan bahwa multikulturalisme dan toleransi menjadi aspek yang perlu diangkat dan dikembangkan sebagai kekuatan yang menjadi daya saing unik kota. Di antara poin-poin yang ada, dua poin ini dirasa mengandung unsur unik dan pembeda yang kemungkinan besar jarang ditemui di kota-kota lain di sekitarnya.

\section{Analisis Data Objek Perancangan}

Berdasarkan data-data yang sudah diperoleh, dapat dilihat bahwa Kota Salatiga mempunyai kekuatan pada sisi multikulturalisme dan toleransinya. Unsur multikulturalisme ditunjukkan dari komposisi penduduk yang beragam latar belakang budayanya. Tak hanya dari segi agama dan kepercayaannya, namun juga dari segi suku bangsanya. Menariknya, sekalipun terdapat banyak perbedaan budaya, kehidupan masyarakat di Salatiga sangatlah harmonis dan kerap kali diwarnai dengan berbagai macam hal yang mengangkat tinggi semangat toleransi.

Warna-warni keberagaman dan toleransi ternyata tak hanya terasa di masyarakat umum saja tapi juga dapat dirasakan di ranah pemerintahan kotanya. Dari segi keanggotaannya, jajaran pemerintahan di Salatiga tak jarang diduduki oleh pejabat yang berasal dari berbagai provinsi lain dari penjuru Indonesia. Produk-produk pemerintahan kota berupa peraturan dan ketetapan pun turut mendukung semangat kesatuan bangsa. 
Dilihat dari sisi sejarahnya, keberagaman dan toleransi yang hidup di Salatiga bukanlah hasil instan dari suatu program terstruktur atau rentetan acara seremonial, tapi lebih merupakan buah dari proses panjang selama berabad-abad. Lewat Prasasti Plumpungan misalnya, bisa dilihat secara tersirat bahwa keharmonisan di dalam keberagaman telah ada sejak 12 abad lebih yang lalu. Pengaruh Islam lewat adanya Legenda Salatiga serta banyaknya pendatang orang kulit putih yang tinggal di zaman Belanda turut mewarnai dan memperkaya khazanah keberagaman sebagai bagian dari pembentukan identitas kota. Dari halhal ini, masyarakat Salatiga mengalami akulturasi budaya yang membuat mereka menjadi "terbiasa" dengan adanya perbedaan.

Setelah masuk pada era kemerdekaan, kemunculan Universitas Kristen Satya Wacana (UKSW) pada tahun 1956 juga semakin menguatkan identitas Kota Salatiga sebagai kota multikultur. Tak hanya sampai di situ, keinginan masyarakat Salatiga akan keharmonisan dalam keragaman juga terpancar dari munculnya gerakan-gerakan dan komunitas pro-toleransi yang ada di kota ini. Paling akhir, ditetapkannya Salatiga menjadi salah satu kota tertoleran di Indonesia oleh Setara Institute menunjukkan adanya pengakuan dari pihak luar mengenai identitas keberagaman dan toleransi di kota ini.

Selain menyajikan segala fakta kemajemukan dan toleransi masyarakat Salatiga yang tinggi, satu hal yang membuat Kota Salatiga tidak terlalu menonjol dibandingkan dengan kota-kota besar lain sekitarnya adalah citra kota yang kurang kuat. Kota Salatiga diduga belum menemukan cara efektif dalam mempromosikan potensipotensi di daerahnya. Selain itu, tempat wisata di Salatiga dinilai kurang dari segi jumlah dan kualitasnya. Selama ini Salatiga hanya dikenal sebagai kota transit pariwisata dan bukan kota tujuan pariwisata.

Salatiga sebenarnya memiliki begitu banyak potensi tersembunyi yang masih perlu dikembangkan dan perlu diketahui oleh masyarakat luas. Dari segi event misalnya, eventevent di Salatiga terbilang cukup banyak, unik, bermutu tinggi dan bahkan sudah ada yang sampai pada level internasional. Tak sedikit juga event-event yang merayakan toleransi antar umat beragama di kota ini. Di bidang kebudayaan, Salatiga mempunyai Drumblek, kesenian kontemporer khas Salatiga berupa pertunjukan musik lapangan seperti marching band namun semua alat musik yang digunakan terbuat dari barang-barang bekas. Potensi lain dari Salatiga adalah soal kulinernya yang terkenal begitu beragam dan murah meriah. Selain segala potensipotensi yang telah disebutkan di atas, Yulianto (Walikota Salatiga) menyebutkan bahwa Salatiga juga merupakan kota yang ramah terhadap investasi. Dalam buku The Profile of Investment Potential in Salatiga City, pada tahun 2014 Kota Salatiga ditetapkan dalam sepuluh besar kabupaten atau kota terbaik se-Indonesia untuk penyelenggaraan Pelayanan Terpadu Satu Pintu (PTSP) di bidang Penanaman Modal (PM).

Tabel 2.3 Analisis Strength,Weakness, Opportunity, Threat (SWOT) Kota Salatiga

\begin{tabular}{|c|c|c|c|}
\hline Strength & Weakness & Opportunity & Threat \\
\hline $\begin{array}{ll}\text { - } & \text { Multikultur } \\
\text { - } & \text { Toleran } \\
\text { Sejarah multikulturalisme } & \text { yang kuat } \\
\text { - } & \text { Pemerintah n yang tidak } \\
\text { diskriminatif. } \\
\text { - } \quad \text { Kebijakan-kebijakan pro } \\
\text { toleransi. } \\
\text { - Posisi geografis strategis } \\
\text { (diapit oleh kota-kota } \\
\text { besar) } \\
\text { Alam sejuk dan peman- } \\
\text { dangan indah }\end{array}$ & $\begin{array}{l}\text { - } \text { Citra kota tidak kuat } \\
\text { - } \text { Belum bisa menjual nilai } \\
\text { toleransi dan multikulturnya } \\
\text { - } \quad \text { Sarana prasarana pariwisata } \\
\text { kurang } \\
\text { - } \\
\text { Akibat letaknya yang } \\
\text { berdekatan dengan kota- } \\
\text { kota besar, Salatiga menjadi } \\
\text { bukan tujuan utama } \\
\text { - } \text { Belum ada usaha serius } \\
\text { untuk melakukan branding } \\
\text { Kota Salatiga }\end{array}$ & $\begin{array}{l}\text { - Punya festival budaya } \\
\text { tahunan tingkat nasional } \\
\text { hingga internasional } \\
\text { - Keunikan perayaan ibadah } \\
\text { dalam nuansa toleransi } \\
\text { - Kesenian kontemporer } \\
\text { Drumblek } \\
\text { - Bisnis kuliner beragam, } \\
\text { murah, dan digandrungi } \\
\text { - Pembelajaran toleransi } \\
\text { bermutu tinggi lewat lembaga } \\
\text { formal maupun non-formal } \\
\text { - Peluang investasi besar }\end{array}$ & $\begin{array}{l}\text { Isu "Salatiga } \\
\text { Kota Mati" } \\
\text { akibat dari } \\
\text { pembangunan } \\
\text { jalan tol Trans } \\
\text { Java }\end{array}$ \\
\hline
\end{tabular}




\section{Konsep Branding Salatiga}

Berdasarkan proses riset serta analisis SWOT Kota Salatiga, terlihat jelas bahwa kekuatan Salatiga adalah pada sisi multikulturalisme dan toleransi di dalam masyarakatnya. Dari benang merah konsep branding ini, dihasilkan big idea branding Kota Salatiga sebagai "Salatiga: Miniatur Indonesia"yang berarti multikulturalisme dan toleransi di Salatiga merupakan miniatur (cerminan nyata) dari spirit ke-Indonesia-an yang begitu beragam namun tetap satu jua. Alasan dipilihnya "Miniatur Indonesia" sebagai tagline juga adalah karena istilah ini dipandang masih dekat dengan istilah "Indonesia Mini" yang memang sudah beredar. Namun karena istilah "mini" dirasa kurang berkarisma dan belum tentu dipahami orang-orang dari seluruh dunia, maka dicari kata yang berkesan lebih berkarisma, dipahami secara luas, dan masih sepadan dengan itu.

Brand positioning dari "Salatiga: Miniatur Indonesia" adalah Salatiga sebagai pioneer kota multikultur dan toleran di Indonesia yang aktif bergerak dalam meneriakkan spirit Bhinneka Tunggal Ika. Selain itu, Salatiga juga sebagai kota pertama di Indonesia yang menjadikan aspek kemanusiaan dan nasionalisme sebagai unique selling point-nya. Selain positioning, dari wawancara, studi pustaka, survey, dan observasi sepanjang penelitian, diputuskan bahwa personalitasbrand yang ingin dibangun adalah humble (sederhana), friendly (ramah), peaceful (damai), diverse (beragam), dan warm (hangat).

Brandstory juga dirancang untuk menterjemahkan "Salatiga: Miniatur Indonesia" menjadi suatu cerita. Cerita inilah yang akan menjadi patokan isi dan nada komunikasi dari segala penerapan identitas visual di berbagai media dengan caranya masing-masing. Brandstory branding Salatiga adalah:

"Pernah membayangkan belajar semua budaya dari seluruh Indonesia? Pernah membayangkan tinggal dengan temanteman dari seluruh penjuru nusantara? Atau, ... pernahkah membayangkan merayakan hari raya didampingi kawan-kawan beda agama? Anda bisa memiliki semuanya di Salatiga.
Salatiga, kota mini di kaki gunung dengan keanekaragaman budaya yang begitu tinggi. Dari Sabang sampai Merauke semuanya ada di sini. Dari para penuntut ilmu sampai para pejabat tinggi, masing-masing bersinergi di dalam harmoni. Semua bersukacita, merayakan spirit Bhinneka Tunggal Ika. Salatiga, mungkin tak semegah candi atau semeriah ibu kota. Tapi singgah sebentar saja, pasti menuai berjuta makna. Belajar mengenali bangsa sendiri yang begitu berbedabeda, belajar berkawan dengan toleransi tanpa harus mengubah jati diri. Semua ada saat Anda pulang ke kota ini, ... di Salatiga, Miniatur Indonesia."

Susunan proritas target audience dari brand Salatiga yang primer adalah kelompok masyarakat usia 17-35 tahun yang proaktif terhadap isu-isu budaya, multikultur, toleransi, dan nasionalisme (SES A-B). Kemudian target audience sekunder sesuai urutan yaitu investor, pejabat-pejabat daerah, turis asing, dan masyarakat secara umum

Cara untuk mengkomunikasikan brand Salatiga secara konkrit diciptakan strategi komunikasi "Tiga M" (Mari Datang, Mari Kenal, Mari Gabung) yang dirasa cocok mewadahi berbagai potensi Kota Salatiga. "Mari Datang" membahas tentang hal-hal fisik Kota Salatiga (seperti event, kuliner, wisata, transportasi, hotel), "Mari Kenal" membahas identitas kota (misalnya multikulturalisme, toleransi, pendidikan), sedangkan "Mari Gabung" berfungsi sebagai portal bisnis di Salatiga.

\section{Identitas Visual Brand Salatiga \\ Logo}

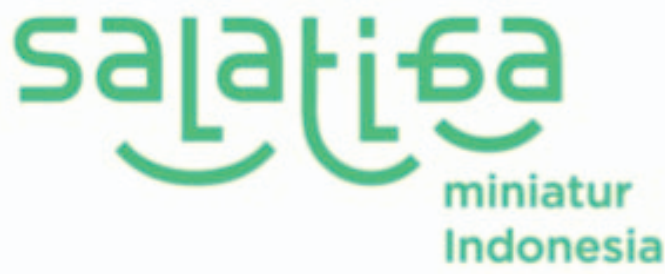

Gambar 1. Logobrand Salatiga (Sumber: dok. Danang, 2015) 


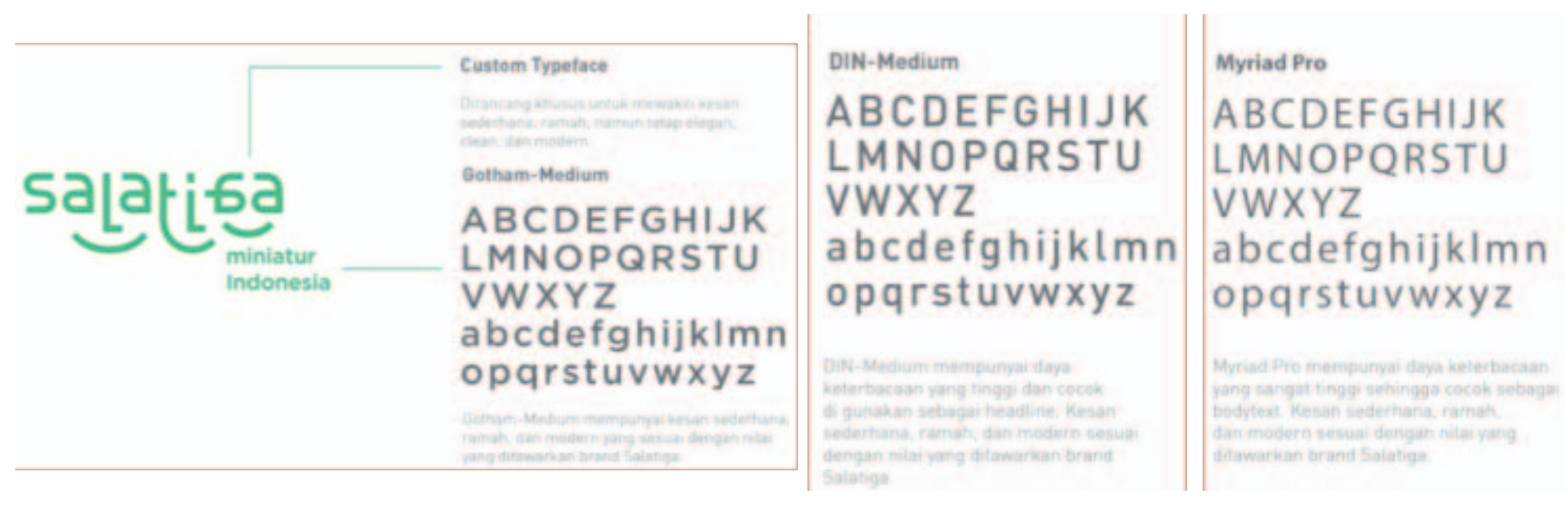

Gambar 2. Sistem tipografi brand Salatiga

(Sumber: dok. Danang, 2015)
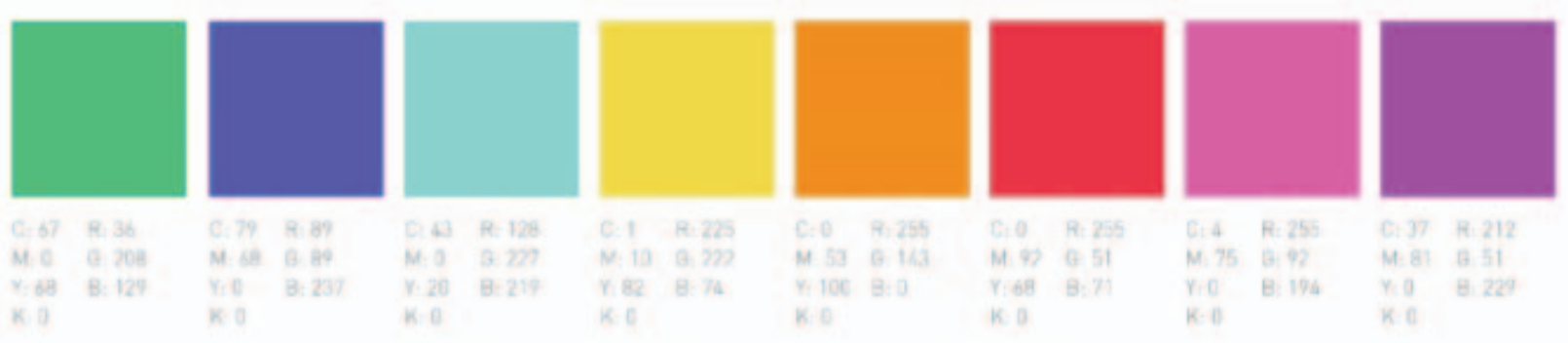

Gambar 3. Sistem warna brand Salatiga

(Sumber: dok. Danang, 2015)

Gagasan yang ditawarkan lewat logo brand Salatiga adalah konsep “Tiga wajah" yang mengandung makna: 1) Multikulturalisme (tiga wajah yang berbeda-beda dalam logo mempunyai makna orang-orang yang beragam); 2) Toleransi (Tiga wajah tersenyum menggambarkan keramahan, penerimaan, dan pada akhirnya toleransi); 3) Keharmonisan, Keseimbangan, dan Keutuhan (angka tigaadalah angka sakral yang memiliki arti lengkap, utuh, seimbang, dan harmoni); dan 4) Legenda Salatiga (dalam legenda Salatiga dikisahkan bahwa Salatiga berasal dari kata 'salah tiga' yang menceritakan tentang kesalahan tiga orang di sebuah lokasi yang terdapat tiga susunan batu besar).

\section{Tipografi}

Konsep huruf yang digunakan dalam perancangan identitas visual Salatiga tetap berpatokan pada brandpersonality yang sudah ditetapkan sebelumnya yaitu merepresentasikan kata sifat 'sederhana', 'ramah', 'damai', 'beragam', dan 'hangat'. Sekalipun tidak semua sifat terwakili, tapi sistem tipografi yang digunakan dalam brand Salatiga mendukung ke arah brandpersonality tersebut. Penggunaan tipografi dalam perancangan identitas visual Salatiga dibagi menjadi logo typeface (yang digunakan dalam logo, jenis huruf custom font dan GothamMedium) serta corporate typeface (digunakan dalam penggunaan biasa, jenis huruf DIN dan Myriad Pro).

\section{Warna}

Konsep warna dalam perancangan identitas visual Salatiga berangkat dari konsep multikulturalisme (beraneka ragam). Sekalipun demikian bila diterapkan secara resmi digunakan warna hijau emerald (R: 36, G:208, B:129; C:67, M:0, Y:68, K:0) sebagai warna utamanya. Warna hijau dipilih karena merepresentasikan suasana Salatiga yang memang hijau dan sejuk. Sedangkan spesifikasi hijau tipe emerald digunakan karena mempunyai makna yang sejalan dengan konsep identitas visual Salatiga yaitu keharmonisan (http://blog.jennifercottreau. 
com/2013/05/emerald-the-green-of-glowingthings/). Warna yang lain merupakan warna yang menggambarkan keberagaman (warna-warni).

\section{Sistem Logo}

Gagasan sistem logo yang diterapkan adalah keberagaman dan fleksibilitas. Di dalam kesakralannya, logo Salatiga mempunyai fleksibilitas yang membuatnya lebih "humanis". Misalnya saja antara komposisi logo normal dengan logo menyamping untuk menyesuaikan pada area penerapannya, serta warna-warni logo yang akan mengikuti kebutuhan penggunaan. Selain itu, logo juga mempunyai sistem modular yang cair dalam komposisinya untuk memberi ruang ekspresi pada penerapannya di berbagai media.

\section{Sistem Pola}

Sistem pola yang digunakan dalam identitas visual Salatiga ingin merepresentasikan semangat keberagaman. Inspirasi utamanya adalah headpiece antar kepercayaan dan budaya dari berbagai daerah di Indonesia yang direspon melalui tiga wajah di dalam logo. Tak hanya berdiri sebagai pengisi ruang estetika, elemenelemen visual ini juga mengungkapkan pesan kuatnya secara tersendiri yaitu memperkenalkan kekayaan keberagaman Indonesia secara visual. Aplikasi pola ini misalnya pada mural di temboktembok pusat kota di mana setiap kepala disertai dengan keterangan asal daerah tradisi yang diwakilinya.
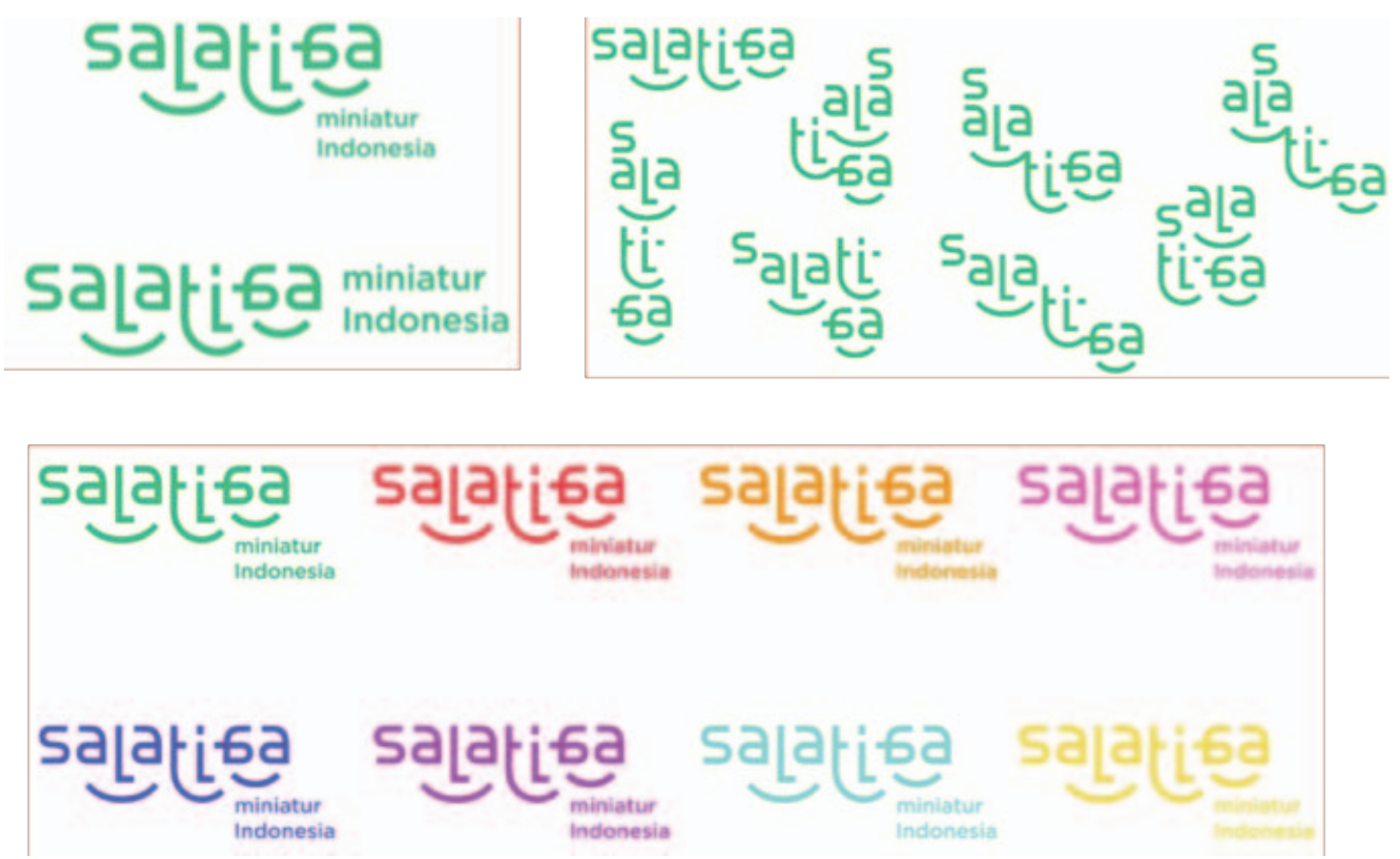

Gambar 4. Sistem warna dan komposisi logo brand Salatiga

(Sumber: dok. Danang, 2015)

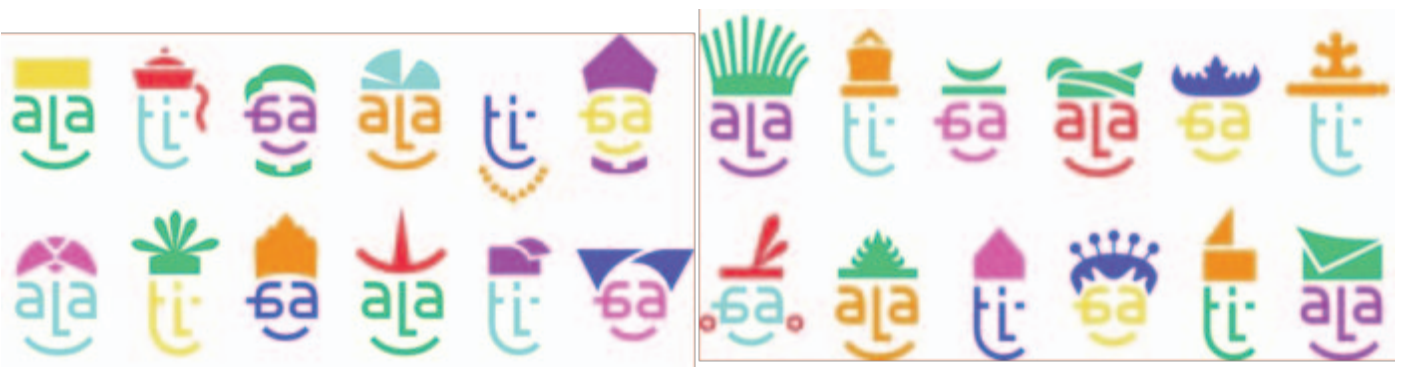

Gambar 5. Sistem pola dan ikon brand Salatiga

(Sumber: dok. Danang, 2015) 


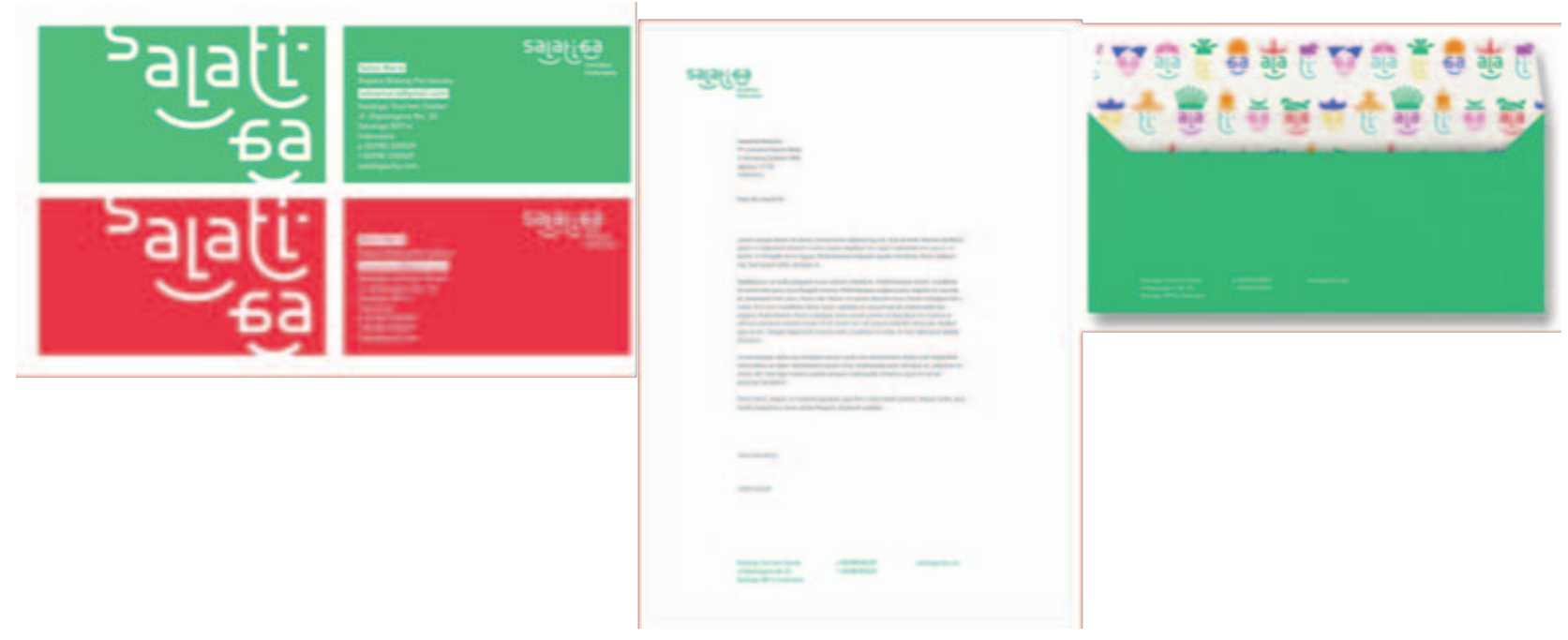

Gambar 6. Stationary brand Salatiga (Sumber: dok. Danang, 2015)
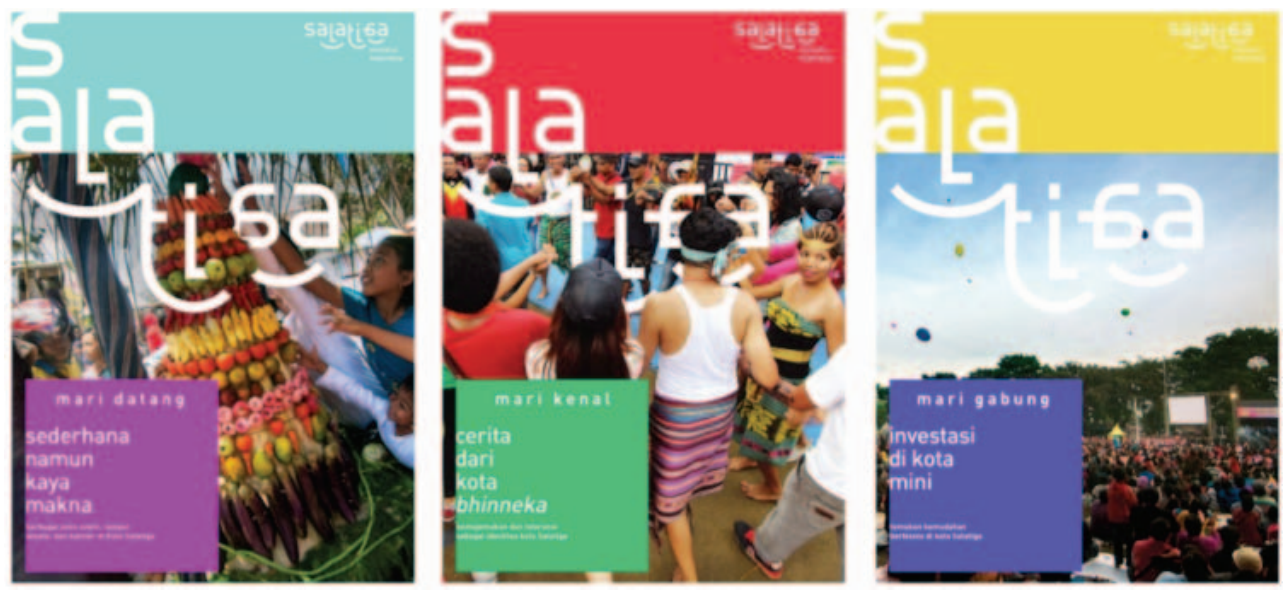

Gambar 7. Seri bookletbrand Salatiga

(Sumber: dok. Danang, 2015)

\section{Aplikasi dalam Media \\ Stationary}

Keberadaan stationary resmi memberikan kualitas pada setiap jalinan komunikasi yang berjalan secara formal, spesifiknya melalui kartu nama, surat resmi, dan amplop yang menyertainya. Ketiga hal tersebut didesain sedemikian rupa agar berkesan formal tapi sekaligus mempunyai ciri keunikan tersendiri yang kuat dan merepresentasikan spirit identitas Salatiga.

\section{Booklet}

Booklet dirancang sesuai dengan strategi komunikasi yang sudah direncanakan sebelumnya yaitu strategi “Tiga M” (Mari Datang, Mari Kenal, dan Mari Gabung). Di dalamnya terdapat informasi-informasi ringan yang berkaitan dengan konsep yang diusung masing-masing kategori. Secara visual, digunakan pendekatan fotografi karena cara ini memberi gambaran nyata dan efektif dalam manyampaikan gagasan mengenai suatu tempat. Konsep desain yang digunakan adalah perpaduan foto dan logo modularagar ekspresif namun tetap menonjolkan identitas brand Salatiga. Dari segi warna, sengaja digunakan warna-warna yang berbeda-beda agar menciptakan kesan keberagaman namun tetap diikat dalam kesatuan layout.

\section{Grafis Pensuasanaan Kota}

Baliho digunakan untuk memperkuat positioning Salatiga sebagai kota multikultur dan toleran. Konsep desain yang diusung dalam 


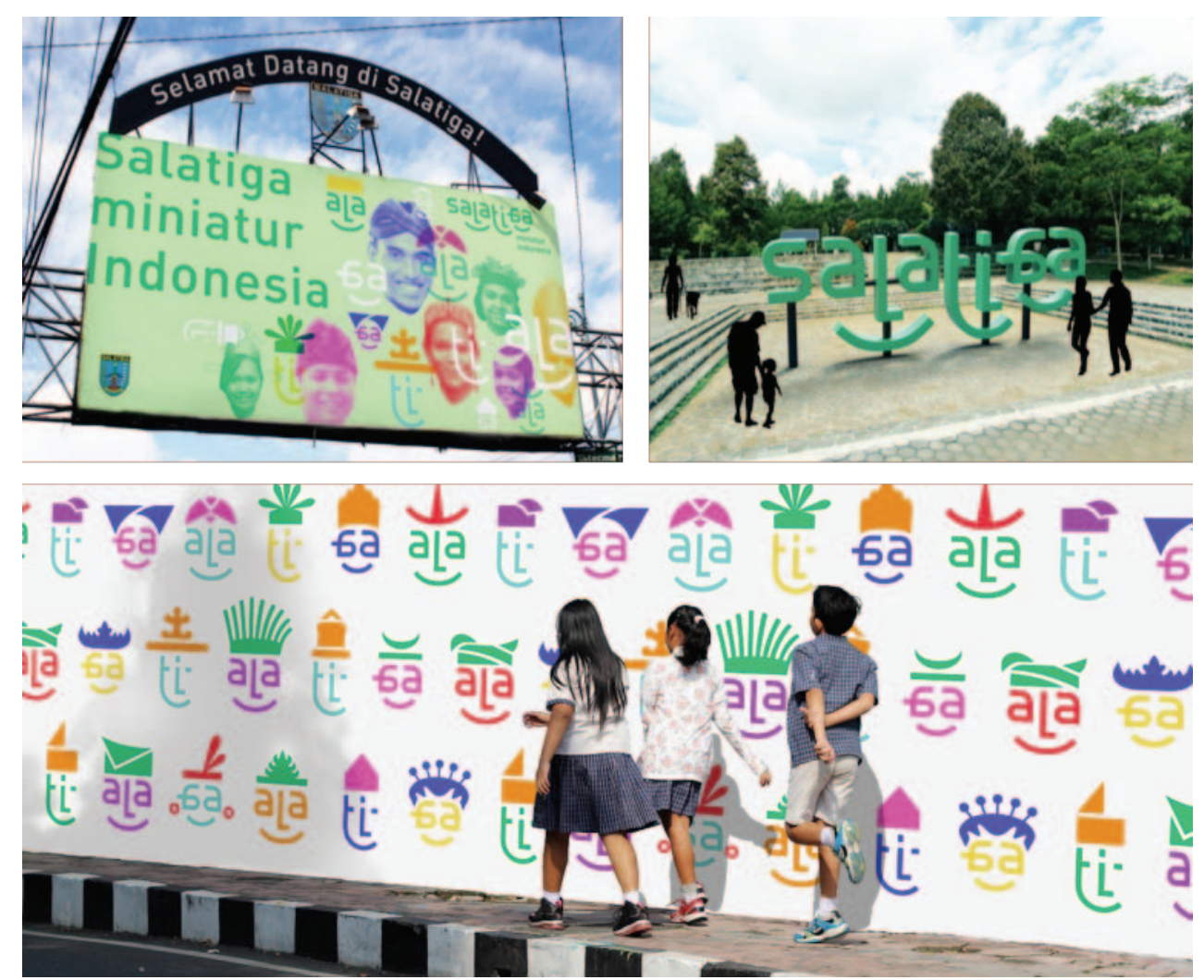

Gambar 8. Grafis pensuasanaan Kota Salatiga

(Sumber: dok. Danang, 2015)

perancangan baliho adalah kombinasi antara fotografi wajah manusia dan icon-icon wajah yang diambil dari logo brand Salatiga. Foto-foto yang digunakan hanyalah bagian kepala karena kepala (wajah) adalah esensi identitas manusia secara visual. Selain itu, konsep wajah juga sejalan dengan konsep logo utama Salatiga (konsep Tiga Wajah).

Desain logo landmark diciptakan sebagai salah satu strategi untuk menyebarluaskan brand Salatiga: Miniatur Indonesia, khususnya melalui media online. Penciptaannya dilatarbelakangi oleh pemikiran bahwa saat ini masyarakat menginginkan sesuatu yang terlihat ikonik dan monumental sehingga dapat dijadikan latar belakang dari foto diri mereka. Semakin banyak orang yang berfoto di suatu tempat (dan kemudian fotonya diunggah ke media sosial), maka popularitas tempat tersebut akan semakin diketahui banyak orang.

Mural dirancang sebagai salah satu media komunikasi dan promosi brand Salatiga. Konsepnya diambil dari pola logo Salatiga yang dikombinasikan dengan beragam headpiece dari berbagai daerah di nusantara. Tujuannya adalah agar masyarakat (khususnya warga lokal) semakin mengetahui bahwa Kota Salatiga sedang berbenah, dan bahwa kekuatan Kota Salatiga adalah pada aspek kebhinnekaannya.

\section{Grafis Transportasi}

Grafis transportasi dirancang agar pensuasanaan branding Salatiga tidak statis melainkan "bergerak dan merambah ke banyak lini”. Angkutan kota yang bergerak dari kawasan pelosok hingga perkotaan menjadi media jitu dalam memperkenalkan brand Salatiga ke semua kalangan tanpa terkecuali.

\section{Website dan Instagram}

Website didesain karena media ini merupakan media yang sangat efektif dalam memuat banyak informasi dan menyampaikannya secara informatif. Website dibuat dengan hierarki yang sesederhana mungkin (menggunakan konsep "Tiga M") sehingga segala informasi dapat terkategorisasi secara jelas.

Sebuah brand perlu mempunyai akun 

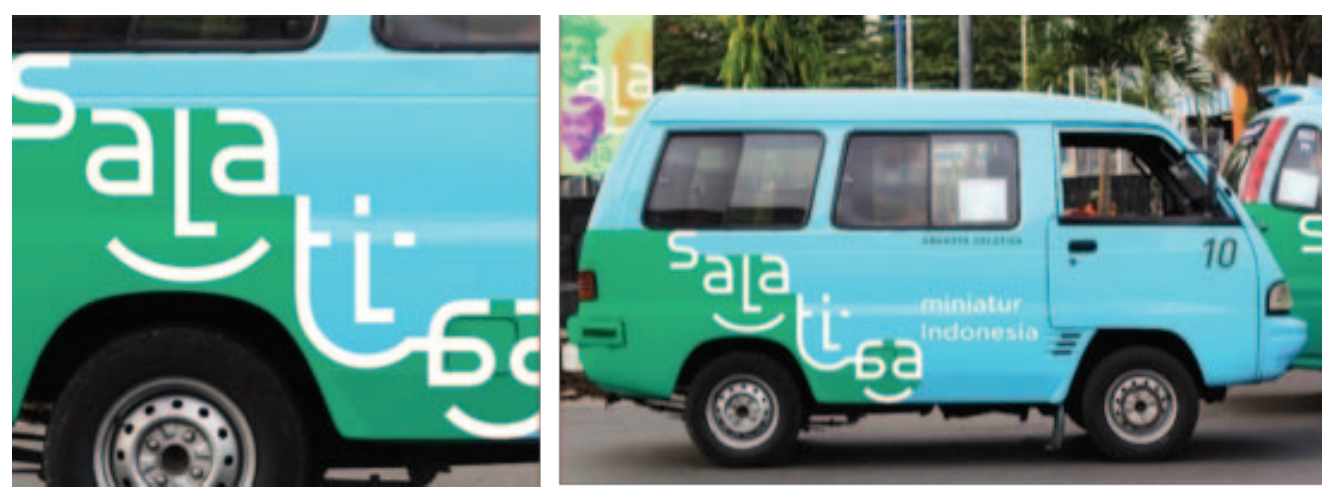

Gambar 9. Grafis angkutan Kota Salatiga

(Sumber: dok. Danang, 2015)
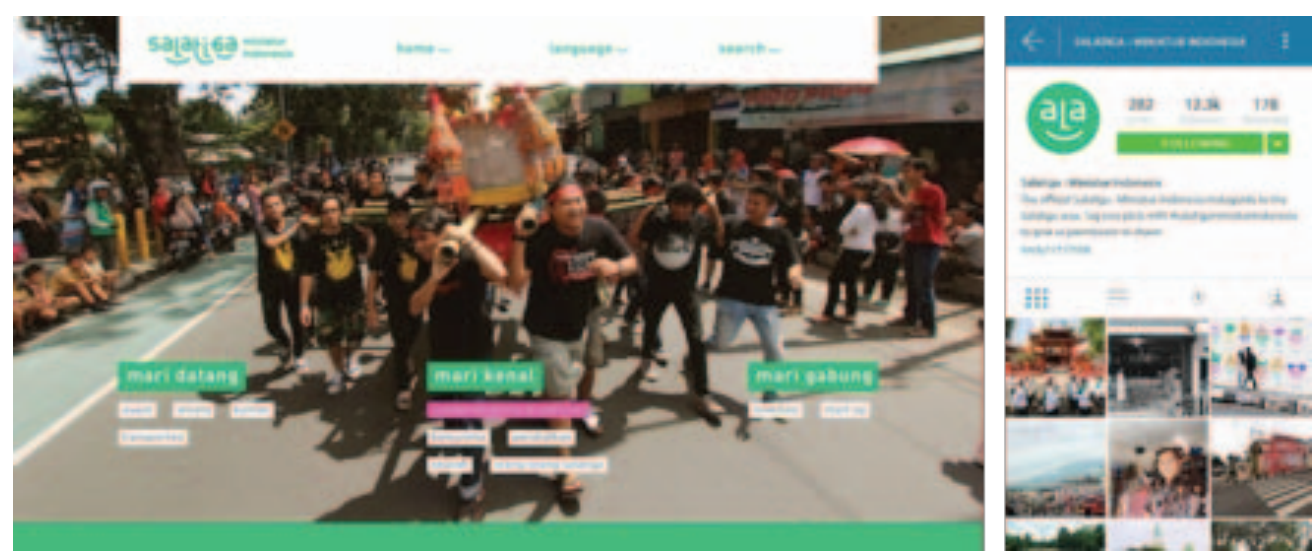

Gambar 10. Website dan instagram brand Salatiga

(Sumber: dok. Danang, 2015)
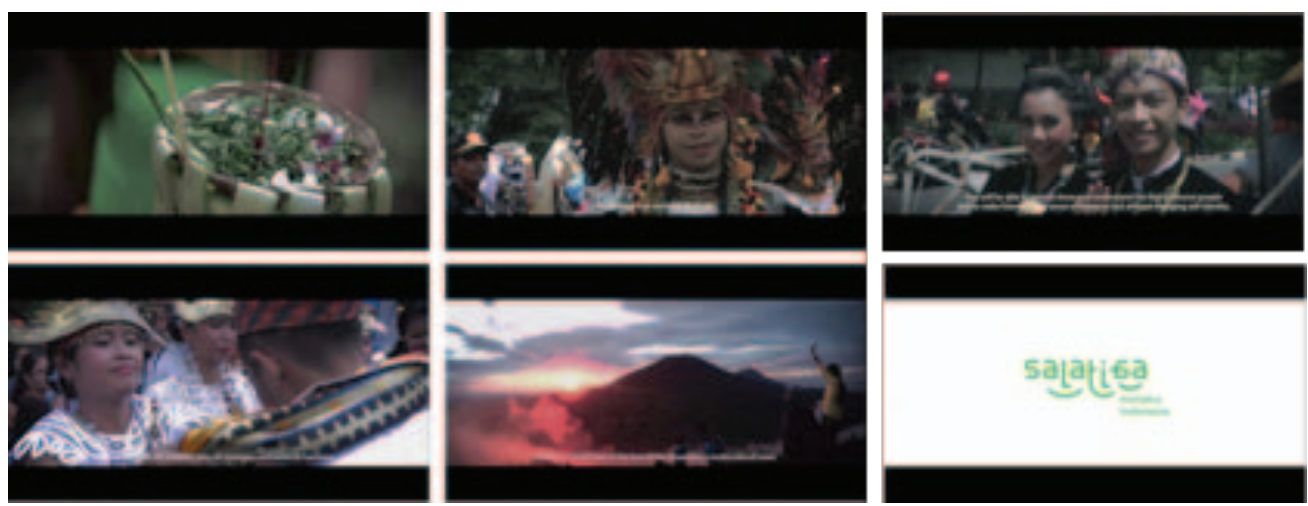

Gambar 11. Potongan gambar video brand Salatiga

(Sumber: dok. Danang, 2015)

jejaring sosial untuk membangun dialog yang baik dengan para konsumen. Selain melalui website, akun Instagram Kota Salatiga menjadi media yang vital untuk menyampaikan "kabar Salatiga" secara up to date, mudah, dan menarik.

\section{Video Promosi}

Video promosi menjadi media efektif bagi penyampaian informasi bergerak tentang sebuah kota. Di dalamnya dinarasikan cerita Salatiga dari berbagai sisi namun tetap berpegang pada benang merah keberagaman dan toleransi. Gabungan antar aspek dalam video (gambar, suara, layout, narasi, dan lain-lain) memberikan gambaran nyata dan menarik tentang bagaimana Kota Salatiga ingin dipersepsikan. 

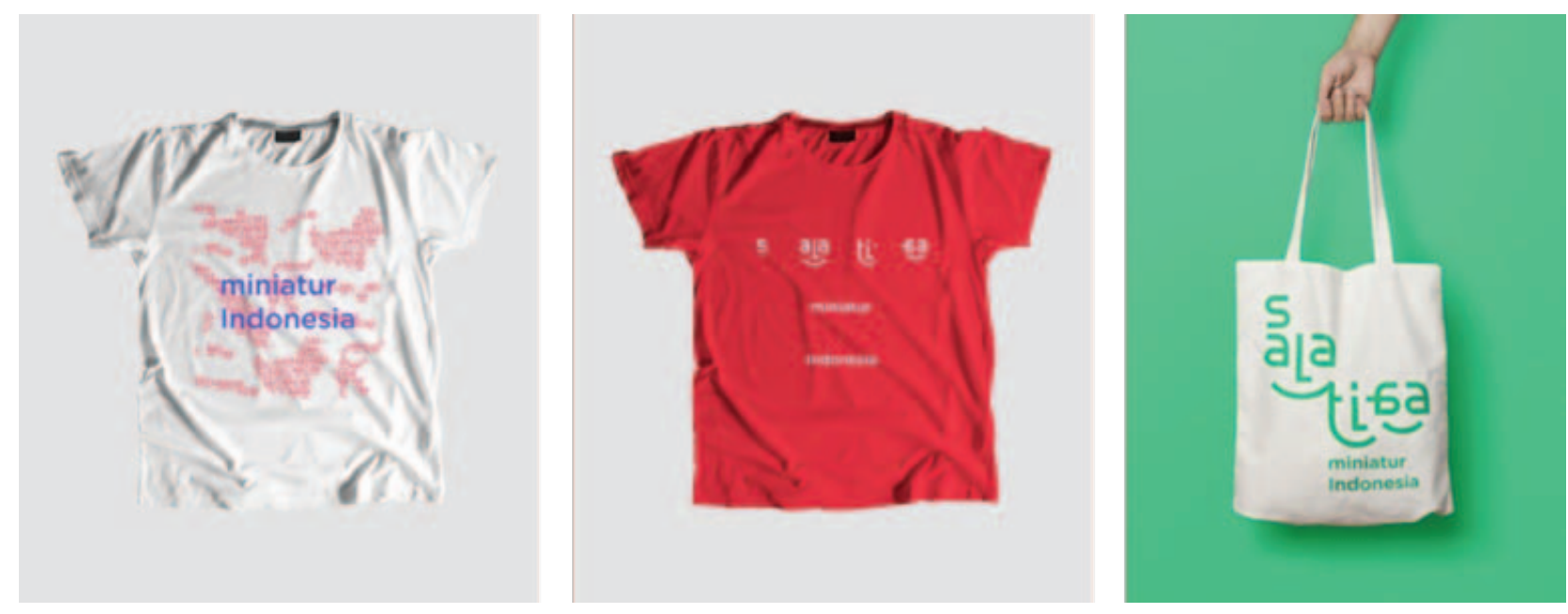

Gambar 12. Suvenir brand Salatiga

(Sumber: dok. Danang, 2015)

\section{Suvenir}

Suvenir dirancang sebagai media promosi sekaligus pengingat terhadap Kota Salatiga. Dengan menggunakan media-media ini diharapkan brand Salatiga akan semakin diketahui secara luas oleh masyarakat.

\section{Kesimpulan}

Hasil penelitian yang sudah dilakukan menunjukkan bahwa Kota Salatiga memiliki identitas unik sebagai kota multikultur dan toleran. Mulai dari penduduknya yang beragam secara agama dan suku bangsa, event-eventnya, komunitas-komunitas protoleransinya, kebijakan pemerintahannya, hingga sejarahnya turut mendukung dan membangun multikulturalisme dan toleransi di Salatiga. Dinobatkannya Salatiga sebagai salah satu kota tertoleran di Indonesia pada tahun 2015 juga menunjukkan adanya "pengakuan" dari pihak luar tentang kuatnya nilai ini di Kota Salatiga. Permasalahannya, identitas Salatiga sebagai kota multikultur dan toleran ini belum diketahui oleh masyarakat luas sehinggaperancangan brand Salatiga (hingga tahap visualisasinya) adalah hal yang harus dilakukan untuk memperkenalkan potensi unik Salatiga di tengah segala tantangan zaman.

Sesuai dengan tujuan perancangan, maka simpulan penelitian dan perancangan terkait dengan tiga aspek, yaitu:

1. Konsep Branding.
Hasil analisis menghasilkan big idea branding Kota Salatiga sebagai "Salatiga: Miniatur Indonesia" yang ingin mengatakan bahwa multikultural dan toleransi di Kota Salatiga merupakan miniatur (cerminan nyata) dari spirit keIndonesia-an yang begitu beragam namun tetap satu jua. Dengan segala personalitas yang dimiliki oleh Salatiga (sederhana, ramah, damai, beragam, dan hangat), kota ini memiliki positioning unik sebagai pioneer kota multikuktur dan toleran yang aktif bergerak dalam meneriakkan spirit Bhinneka Tunggal Ika di Indonesia. Melalui strategi komunikasi "Tiga M" (Mari Datang, Mari Kenal, Mari Gabung) Kota Salatiga dapat memperkenalkan identitas tangible dan intangiblenya kepada target audience yang dituju (masyarakat usia 17-35 tahun yang proaktif terhadap isu-isu terkini).

\section{Identitas Visual.}

"Salatiga: Miniatur Indonesia" diterjemahkan ke dalam logo dengan konsep "Tiga Wajah" yang menggambarkan multikulturalisme, toleransi, keramahtamahan, keharmonisan, dan legenda Kota Salatiga. Sistem logo dibuat fleksibel baik secara warna, komposisi, maupun dalam penggunaannya sebagai ikon agar merepresentasikan spirit keanekaragaman serta membuka banyak peluang aplikasi. 
3. Media-media yang digunakan.

Identitas Salatiga sebagai Miniatur Indonesia diterapkan dalam berbagai aplikasi seperti stationary (kartu nama, kop surat, amplop), booklet, environmental graphics (baliho, logo landmark, mural), grafis transportasi, website (termasuk media sosial), video promosi, dan suvenir (di antaranya kaos dan tote bag).

\section{Daftar Pustaka}

Adisasmita, R. (2015). Teori Pertumbuhan Kota. Yogyakarta.: Graha Ilmu.

Dinnie, K. (2011). City Branding: Theory and Cases. New York: Palgrave Macmillan.

http://deklarasi-sancang.org/salatiga-denganwarga-berbhineka. (n.d.).

Kavaratzis, Mihalis, Warnaby, Gary, Ashworth, \& J., G. (2015). Rethinking Place Branding Comprehensive Brand Development for Cities and Regions. New York: Springer.

Moilanen, Teemu, \& SeppoRainisto. (2009). How to Brand Nations, Cities, dan Destinations: A
Planning Book for Place Branding. New York: Palgrave Macmillan.

Munir, S. (2017). Hindari Jadi Kota "Mati", Daerah Harus Berbenah. Retrieved from http://properti.kompas.com/read

Salatiga, P. K. (2015). Selayang Pandang Kota Salatiga.

Supangkat, E. (2012). Salatiga: Sketsa Kota Lama. Salatiga: Griya Media.

Wheeler, A. (2013). Designing Brand identity: An Essential Guide for The Whole Branding Team. New Jersey. New Jersey: John Willey and Sons.

Widiarto, Tri, Gultom, R., Ruagadi, B., Winanto, A., \& Kusjadi. (2006). Sejarah Perkembangan Universitas Kristen Satya Wacana (19562006). Salatiga: Widya Sari Press.

Wisnu, A. (2015). Ini 10 Kota Paling Toleran Versi Setara Institute.

Yananda, M.Rahmat, U. S. (2014). Branding Tempat: Membangun Kota, Kabupaten, dan Provinsi Berbasis Identitas. Jakarta: Makna Informasi. 